DOI https:/ / doi.org/10.32837/app.v63i0.5

УДК 321

\author{
Пехник А. В. * (НУ «ОЮА») \\ Кройтор А. В. ** $(\mathrm{HY}$ «ОЮА»)

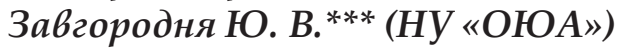

\title{
ТЕОРІЯ РИЗИКУ: ІСТОРІЯ ТА СУЧАСНI ПІДХОДИ
}

\section{RISK THEORY: HISTORY AND MODERN APPROACHES}

*Alevtina Pekhnyk - PhD in Political Science, Associate professor, Political Theories Department, National University "Odesa Law Academy" (23, Fontanska Doroha St., Odesa, Ukraine).

**Artem Kroitor - PhD in Political Science, Political Theories Department, National University “Odesa Law Academy” (23, Fontanska Doroha St., Odesa, Ukraine).

***Yuliia Zavhorodnia - PhD in Political Science, Political Theories Department, National University "Odesa Law Academy" (23, Fontanska Doroha St., Odesa, Ukraine).

«Все життя - це управління ризиками, а не їх виключення». Уолтер Рістон

\section{Abstract}

The article presents an analysis of various theories of risk. The publication outlines the problem area of the application of the theory of risk to the political process, establishes a general understanding of the definition of risk, reproduces the historical process of creating its classification and typology, analyzes the prerequisites for the creation of a single concept of risk, the integration of disparate approaches and thoughts, methodological approaches and obtaining new subject knowledge on this basis. The main task is to attract scientists and practitioners to a discussion on one of the most pressing and complex problems and to give impetus to detailed and comprehensive research in this area.

The theoretical and conceptual approaches to the definition of risk have been developed in the broad context of the most extreme states of society and reflect the economic, cultural, political, social, environmental, and legal aspects of risk. As a result of multi-dimensionality and universality, the risk is the subject of much 
interdisciplinary research, and the term itself is a general scientific concept. This indicates an interest in the study of the components of risk phenomena both from the representatives of technical knowledge and, to a large extent, from representatives of the social sciences. In the dynamics of the growth of risk concepts, the change in the substantive content of risk in the process of development and complication of structures of modern societies is reflected. The transformation of the abstract concept into concrete terms on the basis of subjective advantages and the transition from conceptual thinking to the operational disclosure of a problem is the main task of any science.

Today, the theory of risk has entered a new level of cognition, when scientists began to distinguish between theoretical and effective risk, which is related to the concept of endometric risk, which occurs when modeling risky situations, taking into account peculiarities of risk perception by the subject. In the case of social risk, the purpose function refers to the solution of social problems, and political aspects are taken into account in risk factors. On the contrary, for political risk, the goal function is related to political problems, and indicators of social and economic processes are taken into account when it comes to precisely the risk factors.

Keywords: risk, instability, uncertainty, security, danger, transformation, change, political process.

Постановка проблеми. XXI століття характеризується інтенсивністю та різноманіттям ризиків, які зростають настільки швидкими темпами, що вчені стали говорити про ризик як невід'ємну характеристику сучасного суспільства, яка здатна привести його до руйнування та загибелі. Сьогодні суспільство породжує все нові види ризиків, які роблять його нестабільним і схильним до саморуйнування. Сучасне суспільство поступово перетворюється на суспільство високого ризику, який стає характеристикою як соціального так й політичного життя.

В процесі пізнання та в прагненні повніше задовольнити свої потреби люди постійно намагаються розширити межі передбачуваності розвитку процесів і явищ. Це ж стосується різних ризиків, які є проявом індетермінізму, неповної визначеності фундаментальних якостей, властивостей щодо того або іншого об'єкту життєдіяльності.

Підвищення якості життя в процесі пізнання світу та практичного використання нових знань, які в значній мірі є невизначеними, завжди стикується з ризиками. Тому завдання науки полягає не в ухиленні від ризиків, а в їх оптимізації по відношенню до тих завдань, які ставить перед собою людина або суспільство. 
Криза в Україні знижує рівень керованості країною, унеможливлює вчасне розв'язання економічних та соціальних проблем, влада втрачає довіру громадян та з'являється загроза демократії. Влада повинна не тільки вміти виводити суспільство $з$ кризи, а й запобігати виникненню нових криз. Щоб мати уявлення про ймовірність виникнення кризи, треба враховувати ризики, у тому числі, й політичні.

Це говорить про актуальність та необхідність звернення то аналізу теоретичного розуміння та концептуального наповнення поняття ризику.

Мета дослідження полягає в окресленні проблемного поля застосування теорії ризику щодо політичного процесу.

Аналіз основних досліджень та публікацій. В галузі теорії ринкової конкуренції слід відзначити розробки теоретичних концепцій інвестиційної діяльності компаній, аналізу стратегій розвитку нафтогазових ТНК, Організації країн-експортерів нафти (ОПЕК) (Дж.Стіглер, А.Алчіян, Ф Хайек); в галузі економетрики, математичного та комп'ютерного моделювання, теорії статистики (Р.Фріш, Я.Тінберген, К. Гренджер); в галузі теорії прийняття рішень і ризику (Н.Догерті, Ч.Кеннеді, К.Зунне, К.Олександр); в галузі оцінки політичного ризику (К.Альтхаус, Ш.Брін, Дж.Сімпсон тощо). Загалом, слід відзначити, що «в сучасній українській науці проблеми ризику, ризикології найбільш розробляються в економічному аспекті, а саме в напрямках розгляду інвестиційних ризиків, механізмів ризикменеджменту, підприємницьких ризиків, господарської діяльності тощо. Цьому пласту присвячено досить багато грунтовних досліджень» (Пехник, 2019, с. 213). Це праці таких вчених як А. Пехник, М. Дамаскіна, А. Грищенко, М. Степура, О. Таран, Л. Бондаренко, О. Колот, Н. Скопенко, В. Кривошеїн.

Ризик проявляється в різних формах практично в усіх галузях життєдіяльності людини, функціонування та розвитку суспільства, їх взаємодії тощо. Прояв ризику в різних сферах діяльності людини викликає появу різних трактувань та концепцій. Значна частина визначень поняття «ризик» пов' язана з двома твердженнями: ризик обумовлений випадковими подіями або процесами; наслідки цих подій або процесів є небажаними. Однак для повного розуміння слід враховувати, що прояви ризику можуть мати й позитивні наслідки. Це дає можливість зрозуміти - чому люди, групи, суспільства чи країни приймають на себе ризик. Поведінка, яка пов'язана з прийняттям 
ризику є балансуванням між випадковими втратами та випадковими винагородами.

В теорії ризику існує багато визначень з різних точок зору, а також його класифікацій, які унаочнюють це складне поняття. Якщо спробувати узагальнити ці визначення, то їх можна об’єднати в наступні два. Як визначає I.Макаров «ризик визначається, як передбачувана подія, яка може нанести комусь шкоду або збиток, тобто мати негативні наслідки. Ризик це певна категорія, яка характеризує відхилення фактичного результату від очікуваного, тобто можуть бути як негативні так і позитивні наслідки від події чи процесу. Рівень ризику майже завжди пропорційний очікуваним витратам, які викликані ризиковою подією та імовірністю ії настання» (Макаров, 2000).

До загальних властивостей щодо розуміння та прояву ризику слід віднести наступне: ризик є багатовимірною характеристикою майбутніх станів світу; ризик пов' язаний з випадковими явищами та процесами; прояв ризику - умовна подія.

Якщо звернутися до історичного аналізу, то слід вказати, що історія формування поняття «ризик» в значній мірі пов' язана зі ставленням людини до майбутнього, а саме слово «ризик» має давнє коріння і в перекладі з італійського означає «наважитися».

У Стародавній Греції міфологізований світогляд був заснований на тому, що майбутнє повністю зумовлено волею та бажанням богів, тобто залежить виключно від поведінки людини.

Виникнення світових релігій, і перш за все християнства призвело до того, що майбутнє набуло неоднозначності. 3' явилося розуміння того, що можливість «різного» майбутнього як в реальному житті, так і після смерті залежить від поведінки людини. Тому з' явилася відповідальність за наслідки своїх дій.

Пізніше відбулося усвідомлення того, що майбутнє залежить не тільки від Бога і почалося біль зрозуміле та виважене вивчення проблем, пов'язаних з ризиком. Одним 3 перших був італійський чернець, професор математики Лука (XV ст.). Пізніше, завдяки розвитку азартних ігор з'явилася можливість прогнозування майбутнього. Саме таким чином, досліджуючи азартні ігри, французький математик, філософ і винахідник Б.Паскаль в 1654 році звернувся за допомогою до математика П.Ферма і в результаті їх співпраці була створена теорія ймовірностей. Вона стала величезним світоглядним і практичним стрибком, який дозволив робити кількісні прогнози майбутнього. 3 того часу наукові інструменти прогнозування по- 
чали витісняти різні пророцтва, ворожбу і тому подібні ненаукові методи.

На початку XVIII століття німецький математик Г.Лейбніц висунув ідею, а раніше, швейцарський математик Я.Бернуллі обгрунтував закон великих чисел і розробив процедури статистики. Пізніше, французький математик А.Муавр ввів поняття структури нормального розподілу та ступінь ризику - стандартне відхилення; Д.Бернуллі визначив очікувану корисність; на яку спирається сучасне розуміння теорії інвестицій. Завдяки теоремі Байеса (теоремі гіпотез) світ дізнався, як впливає на прийняття рішень ступінь інформованості про об'єкт управління.

Тобто, наукові дослідження, відкриття основних законів і розробка практично всіх сучасних інструментів управління ризиками відноситься до XVII-XVШ століть. Промислова революція, соціальні потрясіння, розширення галузей життєдіяльності людини істотно збільшили сфери прояву ризику та одночасно сформували ставлення до майбутнього як частково прогнозованого розвитку світу. Тут слід відзначити розробку теорії статистичної регресії англійським математиком Ф.Галтоном в 1886 році.

Як правильно визначає Вишняков, «ризик притаманний будь-якій сфері людської діяльності, що пов' язано з безліччю умов і факторів, які впливають на результат (позитивний або негативний) прийнятих рішень». На думку вченого «ризик недоотримання намічених результатів особливо проявляється при загальності соціальних та політичних відносин, конкуренції учасників політичної діяльності» (Вішняков, 2008). I з цим слід погодитися.

Існує два головних різновиди ризику, які необхідно враховувати для того, щоб зрозуміти, що відбувається в сучасному світі. Перший різновид умовно можна назвати зовнішнім ризиком. Зовнішній ризик - це ризик, причина якого знаходиться поза нас самих: вона пов' язана $з$ незмінними традиціями або законами природи. Інший різновид становить ризик, пов'язаний з нашим пізнанням навколишнього світу. До категорії рукотворного ризику відносяться ситуації, 3 якими людство практично не стикалося раніше в історії, наприклад, більшість екологічних ризиків, які пов'язані з глобальним потеплінням. Безпосередній вплив на них здійснює посилення глобалізації.

Говорячи про розуміння ризику слід також звернути увагу на таке поняття як «невизначеність». Американський вчений Ф.Найт звертає на це увагу і говорить, що про ризик як про кількісний рівень 
невизначеності. Математики О.Моргенштерн та Дж.Нейман встановили взаємозв' язок понять «невизначеність» та «ризик» і відобразили його в імовірному трактуванні ризику.

Остаточно наука про ризик сформувалася тільки наприкінці XX століття завдяки практичним потребам забезпечення безпеки та стабільності суспільного відтворення.

Під час знаходження України у складі Радянського Союзу ситуація з дослідженням ризику була незадовільною. До середини 1930-х рр. ризик був віднесений до явищ капіталістичного господарства, тому що не поєднувався з проголошеним плановим характером розвитку економіки. Ігнорування проблем ризику досягло такого ступеня, що поняття «ризик» навіть не включалося до енциклопедичних видань. Однак світовий досвід показує, що ігнорування або недооцінка ризику (в його різних проявах) при розробці тактики і стратегії політики, прийнятті конкретних рішень неминуче стримує розвиток суспільства.

Знову виникнення інтересу в Україні до прояву ризику в пов'язано з відомими подіями розпаду Радянського союзу і зміни системи життєдіяльності суспільства.

Ризик проявляється через взаємодію людини з іншими суб'єктами та об' єктами різних сфер життєдіяльності і набуває об'єктивного змісту ризику, який вимірюється і $є$ незалежним від людського сприйняття (його можна ідентифікувати, оцінювати та прогнозувати на базі фундаментальних закономірностей); та суб'єктивного змісту ризику, пов' язаного з його індивідуальним сприйняттям (дана сфера ризику відноситься до ментального стану індивідуума, який потрапляє до ситуації невизначеності або сумнівів щодо наслідків деякої події). Відповідно розрізняють реальний та уявний ризики.

Тому, що ризик пов' язаний з діяльністю в умовах, з одного боку, реально існуючої невизначеності, а з іншого - вибору зацікавленим індивідуумом певних альтернатив і розрахунком імовірності їхнього результату, то він є діалектичною єдністю об'єктивного та суб'єктивного. 3 цієї точки зору ризик ототожнюється 3 діяльністю, пов'язаною $з$ подоланням невизначеності в ситуації неминучого вибору, в процесі якої існує можливість кількісно та якісно оцінити ймовірність досягнення передбачуваного результату, невдачі та відхилення від мети.

На сьогодні на практиці використовують кілька концепцій ризику. 3 огляду на те, що ризики пов'язані з перетворюючою діяльністю 
людини в процесі пізнання природи, реальності, їх непізнаними сторонами, що проявляється у вигляді шкоди для людини, то частіше часто ризик пов' язують з поняттями небезпеки і / або загрози. Обгрунтовують цю думку Лесько та Причепа, які відзначають, що в рамках даної концепції знаходяться «розглядають негативні події, які заподіюють шкоду людині чи суспільству, а під ризиком розуміють можливість настання подій з негативними наслідками, тобто, це можливість реалізації передбачуваної небезпеки. Управління ризиками - це способи зменшення ймовірності настання негативних подій і (або) наслідків від них за допомогою заходів, які вимагають розумних витрат» (Lesko, Prychepa, 2017, с. 2-10).

Концепцію ризику як невизначеності використовують в теорії прийняття рішень, теорії ігор, інвестування, а ризик-менеджмент в їі рамках спрямований на зменшення дисперсії між очікуваними результатами і реальними.

Концепція ризику як можливості заснована на взаємозв' язку між ризиком та позитивними результатами. Чим вищий рівень ризику, тим вищим повинен бути потенційний позитивний результат. Тут частіше використовують термін «шанс», а ризик-менеджмент означає використання засобів щодо максимуму результату при одночасному обмеженні втрат. Вона також використовується при управлінні й політичними ризиками.

Ризик - це невизначеність щодо можливих втрат на шляху до мети. Будь-яке вкладення політичних ресурсів з усвідомленою метою отримати позитивний результат залучає до розгляду питання про співвідношення ризику і потенційного позитивного результату. Останнє має бути досить привабливим для політика. Чим вище ризикованість політичної ситуації, тим більшим повинен бути результат (наприклад, виборча кампанія).

3 точки зору реалістичного підходу ризик означає стан небезпеки, загрози, який викликає прагнення людей захиститися від можливих втрат. Ризик, в цьому випадку, розглядається у науково-технічних і економічних термінах, які використовуються в економіці, статистиці, екології, страхуванні, епідеміології та управлінні надзвичайними ситуаціями. Вихідним моментом ризику тут є поняття небезпеки (шкоди), а також твердження про можливість передбачення їх настання та вимірювання наслідків. Ризик трактується як об'єктивний та пізнаваний факт - потенційна небезпека або вже заподіяна шкода, яка може бути виміряна незалежно від соціального сприйняття та 
культурного середовища. При цьому прихильники даного підходу визнають, що ризик може бути помилково оцінений в рамках того або іншого способу соціальної інтерпретації.

У більш вузькому аспекті ризик розуміється як діяльність в умовах переходу від стану невизначеності до стану визначеності (або навпаки), коли з'являється обгрунтована можливість вибору при оцінці ймовірності досягнення передбачуваного результату, невдачі та відхилення від мети, з урахуванням діючих суттєвих норм. Тут слід підкреслити, що ризики конструюються за допомогою активного сприйняття та вибору людей в процесі, обумовленому громадськими цілями та нормами соціальної діяльності. На основі цього виникає інший науковий напрямок дослідження ризику, в якому головна увага зосереджена на філософських, соціальних, політичних та культурних аспектах.

Можна виділити наступні напрямки аналізу ризику: культурносимволічний напрям (М.Дуглас), концепція «суспільства ризику» (У. Бек та Е. Гідденс) та концепція «калькулятівної раціональності». Цікаві моделі соціологічних досліджень ризику також запропоновані І.Дев'ятко та К.Гавриловим (Дев'ятко, Гаврилов, 2007, с. 65). В кожному з зазначених підходів існує помірна та радикальна лінії розуміння ризику. Прихильники помірної концепції вважають, що ризик є об'єктивно-суб'єктивним відображенням існуючої небезпеки. Прихильники радикальної теорії стверджують, що ризику як такого не існує. Можна лише говорити про суб'єктивне сприйняття ризику, яке обумовлене економічними, духовними, політичними та соціальними факторами і умовами, які характерні для конкретної соціальної або політичної ситуації.

При управлінні ризиком мова повинна йти не про мінімізацію ризику, а про його оптимізацію. Можливість управління ризиком створює передумови для прогресу людства за рахунок освоєння їм нових сфер діяльності.

В теорії управління ризик розглядається як атрибутивна загальна суспільна характеристика будь-якого виду доцільної діяльності людини, що здійснюється в умовах ресурсних обмежень і наявності можливості вибору оптимального засобу досягнення усвідомлених цілей в умовах інформаційної невизначеності. Тому, інтегральне визначення ризику виражається в тому, що ризик - це є можливість того, що дії людини або їх результати приведуть до негативних або позитивних наслідків. 
В даний час активно розвиваються спеціалізовані наукові дисципліни, пов'язані з дослідженням ризику, розширюються галузі практичного застосування методів управління ризиком. В такому ракурсі ризик виступає як одна з властивостей повсякденного життя і трактується у близькості до таких філософсько-методологічних понять як «матерія», «інформація», «енергія» тощо.

Науковий напрямок, який сформувався на основі комплексних теоретико-прикладних досліджень ризику, отримав назву ризикологія. Одним з центральних завдань ризикології є винахід різних способів захисту від ризиків на галузевому, національному та глобальному рівнях, розробка законодавства та створення відповідних структур безпеки, локалізація та мінімізація природних, техногенних та соціогенних ризиків на основі їх ранньої діагностики, ідентифікації та попередження. 3 урахуванням масштабності використання категорії ризику в західних соціальних та політичних науках ризикологія може стати інтегральною теорією.

На практичному рівні мова йде про управління ризиком або ризик-менеджмент. Об'єктом досліджень в рамках ризикменеджменту виступає феномен ризику в різних його прикладних рівнях та розглядається, у більшості випадків, в інструментальному аспекті. Основна увага приділяється аналізу та пошуку ефективних засобів комунікації, виробленню рішень та управлінню в ситуації настання ризику в тих чи інших галузях людської життєдіяльності: це політичні ризики, бізнес-ризики, ризики військової безпеки, психологічні та комунікативні аспекти ризику, управління ризиками в надзвичайних ситуаціях, правові та правозастосовчі ризики, управлінські ризики.

Крівошеїн виділяє ще соціально-перцептивну концепцію ризику, яка «визначає параметри сприйняття ризику як можливості передбачення загроз, які пов' язані з суб'єктивним рішенням. В рамках даної концепції зроблено спробу поглиблено вивчити ризик як чинник, який формує поведінковий простір індивіду. Процес сприйняття ризику характеризується такими ознаками: сприйняття ризику - динамічний процес, оскільки він не є постійним процесом, а з часом може піддаватися певним змінам; сприйняття ризику - інтерактивний феномен, оскільки індивідуальне сприйняття ризику опосередковане сприйняттям ризику місцевою громадою; дія соціальних інститутів 3 мінімізації впливу ризиків змінює їх соціальну інтерпретацію» (Кривошеїн, 2009). 
Прихильники культурно-символічної концепції намагаються довести, що ризик - це «соціокультурний факт, який відрізняється від природного катаклізму та виникає у випадку небезпеки нанесення шкоди суб'єкту чи об'єкту реалізації ризику або недостатньої захищеності від небезпеки. Ризик-тривожність та ризик-толерантність $є$ культурними орієнтаціями, які впливають на рівень ризикогенності в суспільстві» (Пономаренко, 2018).

Культурно-символічні концепції репрезентовані трьома напрямками: перший пов' язаний зі специфікою культури, яка задає той чи інший рівень ризиків; другий - 3 історичною динамікою як специфічним джерелом нових ризиків; третій - 3 розробкою технологій управління культурними ризиками.

Фундатор теорії «калькулятивної раціональності» М.Фуко та його послідовники зосереджують свою увагу на з'ясуванні того, «як різні концепції ризику породжують специфічні норми поведінки, які можуть бути використані для мотивування індивідів до вільної участі у процесах самоорганізації в ризикогенних ситуаціях» (Фуко, 1978).

Деякі дослідники, зокрема, О. Ренн, П.К. Штерн, Х.В. Файнберг, Е. Петерс та інші, запропонували синтетичний підхід до дослідження ризику, вказуючи на поєднання структур ризику та змін в ієрархії соціальних цінностей, на які впливає ризик. 3 цим підходом пов'язана концепція ризику, в основі якої лежить прагнення ризику або надання переваги йому як життєвої стратегії. Спробою поєднати культурно-символічний підхід, проблематику «суспільства ризику» й аргументи М. Фуко для того, щоб дати синтезоване розуміння ризику як соціального явища, є створення соціокультурної теорії ризику. Це роботи таких вчених як Д.Лаптон, П. Каплан та Е.Скотт. Кривошеїн визначає цей напрямок як такий, що забезпечує «важливий опис перспективи та приклади для вивчення, але обмежений у теоретичному або дискусійному плані» (Кривошеїн, 2009, с. 30).

В теорії ризиків можна виділити такі об'єкти: джерела небезпеки і невизначеності в природі, техносфери, суспільстві, економіці (бізнесі) і політиці; об'єкти ризику або безпеки (людина; утворені соціальні системи; держава як форма соціальної організації суспільства; світове співтовариство; природне середовище як умова для подальшого сталого розвитку людства); суб'єкти забезпечення безпеки - людина; організації; держава; міждержавні органи. Останні в основному формуються з метою забезпечення міжнародної безпеки, недопущення загальної ядерної війни, вирішення глобальних проблем су- 
часності; зв' язки між джерелами небезпеки та об'єктами безпеки, що реалізуються у вигляді небезпечних явищ (зокрема, політичних) та призводять до криз; нестабільність політичного, економічного, правового середовища, яка веде до прийняття рішень в умовах невизначеності; системи захисту об'єктів ризику, які створюються суб'єктами забезпечення безпеки (системи особистої, колективної і глобальної безпеки).

Джерела виникнення невизначеності в суспільстві різноманітні. До загальних причин, які сприяють утворенню невизначеності та згодом ситуацій ризику, зазвичай вказують на обмеженість тих або інших (матеріальних, фінансових та інших) ресурсів при прийнятті та реалізації рішень, неповноту або викривленість наявної інформації, неможливість однозначно розкрити зміст явищ або процесів. Невизначеність генерується існуванням безлічі відмінностей у соціально-політичних установках, ідеалах, оцінках, стереотипах поведінки та цінностей людей стосовно різноманітних суспільних відносин, а також під впливом результатів науково-технічного прогресу на соціально-економічні, політичні та духовні умови розвитку суспільства. Тобто, невизначеність пов' язана з можливістю фіксувати виникнення в діяльності суб'єкта безлічі різноманітних ситуацій та наслідків.

Всі джерела небезпеки діють на всі об'єкти ризику. Всі суб'єкти забезпечення безпеки також можуть в тій чи іншій мірі впливати на об'єкти ризику.

Незважаючи на те, що не представляється можливим встановити загальновизнане визначення предметної області поняття «ризик», більшість науковців відзначають наступні сутнісні ознаки ризику.

- Ризик виходить з принципової невизначеності реальності. Недостатність інформації, спонтанність багатьох явищ, що відбуваються в житті людей, обмеженість ресурсів при прийнятті та реалізації рішень, а також наявність антагоністичних тенденцій у соціальнополітичному розвитку вносить елементи невизначеності та хаосу, створюючи умови для виникнення ризику. Категорія невизначеності $\epsilon$ основою інформаційного підходу до розуміння сутності ризику.

- Імовірнісний характер настання як несприятливих, так і сприятливих наслідків ризику. Це означає, що ризик не можна обмежувати тільки ймовірною шкодою або втратами. Ризик несе в собі не тільки негативні, а й позитивні можливості, урахування та використання яких є важливим моментом у процесі прийняття рішень про ставлення до тих чи інших ризиків. Ці два аспекти ризику - його негативна 
та позитивна сторони - виявилися вже в новий час. Ймовірність, в даному випадку, визначається як об'єктивна можливість появи події.

- Відносність досягнення поставлених цілей та результатів. Діяльність людини відбувається під впливом факторів, сутність і сила яких не завжди може бути об'єктивною та виміряною в абсолютних показниках. Постійна зміна пріоритетів одних інтересів по відношенню до інших породжує ситуації, коли, досягнення яких-небудь результатів раніше вважалося релевантним та продуктивним і за певних обставин, може набути зворотного значення серед учасників політичного процесу. Відсутність впевненості у суб'єкта може призвести до сваволі та помилки в оцінці характеру особистих і групових інтересів і в конфліктних ситуаціях.

- Орієнтація на майбутнє. Ризик отримує своє вираження в реальності, що включає в себе елементи цілепокладання, прогнозування та планування очікуваних станів, процесів та явищ. Тобто, ризик з' являється як реакція на ситуацію, що склалася. В результаті, компонент майбутнього в ризику робить його найважливішою установкою в процесі прийняття рішень та центральною категорією в описі майбутнього. Ризик слід розглядати як специфічну форму соціально-політичної комунікації, спрямовану до оцінку невідомого майбутнього в сьогоденні.

- Суперечливість. Ризик сприяє здійсненню ініціатив, новаторських ідей, соціальних експериментів. Це дає шанс подолати інертність, стереотипи та обмеження, що перешкоджають впровадженню нововведень. 3 іншого боку, це може призвести до волюнтаризму, недооцінки істотних сторін життя, до тих чи інших політичних, соціально-економічних, правових і моральних конфліктів. Особливо, якщо рішення приймається без адекватних закономірностей розвитку ситуації підготовчих заходів.

- Альтернативність. Ризик передбачає вибір з двох та більше варіантів рішення. При відсутності вибору ризик як такий неможливий. Наявна в цьому випадку ситуація може бути охарактеризована станом «визначеність». Але, слід підкреслити, що відмова від вибору - це також варіант вибору, альтернатива. Залежно від конкретного змісту ситуації вибору альтернативність має різний ступень складності та структурується різними засобами. Для цього використовується класифікація проблемних ситуацій, що вимагають вибору тієї чи іншої альтернативи. Це три типи завдань: добре структуровані, погано структуровані та неструктуровані. Кожному типу завдань відповідає 
певний набір методів і методик аналізу, оцінки та формулювання рекомендацій.

- Еволюційність. Як зовнішні, так і внутрішні ризики здатні еволюціонувати. Серед ризиків існує природний відбір та безліч механізмів трансформації, обумовлених природою тих об'єктів, в яких вони повинні бути. Вплив на ризик передбачає відповідь зниження його рівня, однак повністю ризик виключити неможливо, тому, що початковий ризик буде змінений та може перетворитися на цілий ряд інших ризиків.

Висновки. Теоретичні та концептуальні підходи до визначення ризику розроблялися в широкому контексті найбільш екстремальних станів суспільства та відображають економічні, культурологічні, політичні, соціально-середовищі, правові аспекти ризику. Як правильно визначено А.Пехник «в результаті багатоаспектності та універсальності ризик є об'єктом багатьох міждисциплінарних досліджень, а сам термін - загальнонауковим поняттям. Це свідчить про зацікавленість у вивченні складових феноменів щодо ризиків як з боку представників технічного знання, так і значною мірою й представників соціальних наук. В динаміці зростання концепцій-ризику відображається зміна предметного змісту ризику в процесі розвитку та ускладнення структур сучасних суспільств. Перетворення абстрактного поняття в конкретні терміни на основі суб'єктивних переваг і перехід від концептуального осмислення до операціонального розкриття проблеми це головне завдання будь-якої науки» (Пехник, 2019, с. 216).

Сьогодні теорія ризику вийшла на новий рівень пізнання, коли вчені стали розрізняти теоретичний та ефективний ризик, які пов' язані між собою поняттям евентологічного ризику, який виникає при моделюванні ризикованих ситуацій з врахуванням особливостей сприйняття ризику суб'єктом. У разі соціального ризику функція мети стосується вирішення соціальних проблем, а політичні аспекти враховуються у факторах ризику. Для політичного ризику, навпаки, функція мети пов' язана $з$ політичними проблемами, а показники соціальних та економічних процесів враховуються, коли мова йде саме про фактори ризику.

\section{תimepamypa:}

Вишняков Я. Д., Радаев Н. Н. (2008). Общзая теория рисков: учеб. пособие для студ. высш. учеб. заведений. 2-е изд., испр. М.: Издательский центр «Академия». 
Гаврилов К. (2007). О конструировании понятия «риск» в социологии. Социология: методология, методы, математическое моделирование (4M), 24, 60-80.

Кривошеїн В. (2009). Культурологічна теорія ризику в структурі політичної ризикології. Науковий вісник Ужгородського університету. Сер. Політологія, соиіологія, філософія, Ужгород, 12, 28-33.

Макаров И. (2000). Управление риском. Риск, устойчивое развитие, синергетика. М.: Наука.

Пехник А. (2019). Політичний ризик: проблеми термінології та змісту в системі наукових знань. Правове життя сучасної України, 213-216.

Пономаренко Т. (2018). Філософський аналіз значення інформаційномережевої парадигми в осмисленні суспільства ризику на шляху до стійкої форми його розвитку. Філософія науки: традиції та інновації, 2 (18), 33.

Фуко М. (1978). Безопасность, территория, население. Лекция 25. Цикл лекции, прочитанных в Коледж де Франс 8 1977-1978 годах.

Lesko O. Y. (2017). Development of approach to anticipatory risk management of the enterprise under uncertainty conditions. Technology audit and production reserves, 4/4(36), 9-15.

\section{References:}

Fuko M. (1978). Bezopasnost, territoriya, naselenie. Lektsiya 25 [Security, territory, population. Lecture 25]. Tsikl lektsiy, prochitannyih v Kolledzh de Frans v 1977-1978 godah [A series of lectures delivered at the College de France in 1977-1978]. [in Russian].

Gavrilov K. (2007). O konstruirovanii ponyatiya «risk» v sotsiologii [On the construction of the concept of «risk» in sociology]. Sotsiologiya: metodologiya, metodyi, matematicheskoe modelirovanie [Sociology: methodology, methods, mathematical modeling] (4M), 24, 60-80. [in Russian].

Kry`vosheyin V. (2009). Kul`turologichna teoriya ry`zy`ku v strukturi polity`chnoyi ry`zy`kologiyi [Cultural risk theory in the structure of political riskology]. Naukovy j visny ‘k Uzhgorods 'kogo universy tetu. Ser. Politologiya, sociologiya, filosofiya [Uzhgorod University Scientific Bulletin. Avg. Political science, sociology, philosophy]. Uzhgorod, 12, 28-33. [in Ukrainian].

Lesko O. Y. (2017). Development of approach to anticipatory risk management of the enterprise under uncertainty conditions. Technology audit and production reserves, 4/4(36), 9-15. 
Makarov I. (2000). Upravlenie riskom. Risk, ustoychivoe razvitie, sinergetika [Risk management. Risk, sustainable development, synergetics]. M.: Nauka. [in Russian].

Pexny`k A. (2019). Polity`chny`j ry`zy`k: problemy` terminologiyi ta zmistu v sy`stemi naukovy`x znan` [Political risk: problems of terminology and content in the system of scientific knowledge]. Pravove zhy ttya suchasnoyi Ukrayiny [The Legal Life of Modern Ukraine], 213-216. [in Ukrainian].

Ponomarenko T. (2018). Filosofs`ky`j analiz znachennya informacijnomerezhevoyi parady`gmy`v osmy`slenni suspil`stva ry`zy`ku na shlyaxu do stijkoyi formy` jogo rozvy`tku [Philosophical analysis of the value of information and network paradigm in the understanding of risk society on the way to a sustainable form of its development]. Filosofiya nauky: trady ciyi ta innovaciyi [Philosophy of Science: Traditions and Innovations], 2 (18), 33. [in Ukrainian].

Vishnyakov Ya. D., Radaev N. N. (2008). Obschaya teoriya riskov: ucheb. posobie dlya stud. vyissh. ucheb. zavedeniy [General risk theory: textbook. allowance for students. higher textbook. institutions]. 2-e izd., ispr. M.: Izdatelskiy tsentr «Akademiya». [in Russian].

\section{Анотація}

Пехник А. В., Кройтор А. В., Завгородня Ю. В. Теорія ризику: історія та сучасні підходи. - Стаття.

В статті представлений аналіз різноманітних теорій ризику. В публікації окреслюеться проблемне поле застосування теорії ризику щуодо політичного процесу, встановлюється загальне розуміння дефініиії ризику, відтворюється історичний процес створення його класифікації та типології, аналізуються передумови створення єдиної концепції ризику, інтеграції розрізнених підходів та думок, методологічних підходів та оттимання на ціий основі нового предметного знання. Головне завдання: залучення вчених і практиків до дискусії з однієї з найактуальніших і найскладніших проблем та надати поштовх до різнобічних та комплексних досліджень в ціій галузі.

Ключові слова: ризик, нестабільність, невизначеність, безпека, небезпека, трансорормація, зміни, політичний процес. 